\title{
Algılanan Hizmetkâr Liderliğin Presentizm (Edimsizlik) Üzerindeki Etkisi: Frigya Bölgesi*
}

The Effects of Perceived Servant Leadership on Presenteeism: Phrygia Region

\author{
Necip ÖZDEMIR**, Esra GÜL YILMAZ*** \\ **Dr. Öğrencisi, Anadolu Üniversitesi Sosyal Bilimler Enstitüsü Yunus Emre Kampüsü, 26470 Tepebaşı, Eskişehir. \\ E-posta: necip_ozdemir_no@hotmail.com \\ ORCID: 0000-0002-9440-5003 \\ ***Dr. Öğr. Üyesi, Afyon Kocatepe Üniversitesi Turizm Fakültesi Ahmet Necdet Sezer Kampüsü, 03200, Afyonkarahisar. \\ E-posta: esragul@aku.edu.tr \\ ORCID: 0000-0003-2826-9768
}

MAKALE BILGILERI

Makale işlem bilgileri:

Gönderilme tarihi: 2 Ekim 2018

Düzeltme: 20 Kasım 2018

Düzeltme: 28 Aralik 2018

Kabul: 3 Ocak 2019

Anahtar sözcükler: Hizmetkâr liderlik, Presentizm, Otel ișletmeleri, Frigya bölgesi.

\section{ARTICLE INFO}

Article history:

Submitted: 2 October 2018

Resubmitted: 20 November 2018

Resubmitted: 28 December 2018

Accepted: 3 January 2019

Key words: Servant leadership,

Presenteeism, Hotel enterprises,

Phrygian region.

\begin{abstract}
ÖZ
Presentizm çalışanların sağlık problemleri yaşamalarına rağmen işe gitmelerini ifade etmektedir ve özellikle hizmet işletmelerinde başarısızlığa ve verimliliğin düşmesine neden olmaktadır. Odak noktasında çalışanların intiyaçlarının bulunduğu hizmetkâr liderlik anlayışı presentizm kaynaklı verimlilik kayıplarını önleyebilir. Bu doğrultuda araştırmanın amacı, Frigya bölgesinde faaliyet gösteren beş yıldızlı otel işletmelerindeki hizmetkâr liderlik davranışlarının çalışanların presentizm düzeyleri üzerindeki etkisini ortaya koymaktır. Alan araştırmasında nicel yöntem kullanılmış ve veriler anket tekniği ile toplanmıștır. Veri analizinde sıklık, yüzde, korelasyon ve regresyon analizlerinden yararlanılmıştır. Araştırma sonuçlarına göre; Frigya bölgesinde faaliyet gösteren beş yıldızlı otel işletmelerindeki hizmetkâr liderlik davranışlarının çalışanların presentizm düzeylerini negatif yönde etkilediği tespit edilmiștir. Presentizm ile negatif yönde en yüksek düzeyde etkisi olan hizmetkâr liderlik alt boyutu ise güçlendirmedir.
\end{abstract}

\begin{abstract}
Presenteeism refers to the fact that employes go to work despite their health problems, and it causes failure and decrase in productivity, especially in service businesses. The understanding of servant leadership based on the needs of the employes can prevent the efficiency losses originated from presenteeism. In this context, the purpose of this study is to reveal the effect of servant leadership behaviors on presenteeism levels of employes working in five-star hotels operating in the Phrygian region. In the field research quantitative method was used and data were collected by questionnaire technique. While carrying out the data analysis, frequency, percent, correlation and regression analysis were used. According to the results of the research, it was detected that servant leadership behaviors affected presenteeism levels of employes negatively. The servant leadership strengthens the sub-dimension, and has a negative relationship with presenteeism at the highest level of influence.
\end{abstract}

\section{Giriş}

Otel çalışanları, sunulan hizmetin bir parçası konumundadır ve müşterilere karşı işletmeyi temsil etmektedirler. Dolayısıyla işletmenin imajı bu hizmetin, müşterinin "memnuniyet" düzeyinde

\footnotetext{
* Bu çalışma, Afyon Kocatepe Üniversitesi Sosyal Bilimler Enstitüsü Turizm İşletmeciliği Anabilim Dalında, Dr. Öğr. Üyesi Esra Gül Yılmaz danışmanlığında yazılan, “Alg̨lanan Hizmetkar Liderliğin Presentizm Üzerindeki Etkisi: Frigya Bölgesi Örneği" başlıklı yüksek lisans tezinden üretilmiştir.
}

bıraktığ1 etkiye göre şekillenmektedir (Çevik ve Akoğlan Kozak 2010: 84-85). İnsanları mutlu etmeyi amaçlayan otel çalışanlarının bu memnuniyeti sağlayabilmesi için kendilerinin de mutlu ve sağlıklı olması gerekir (Aydın Tükeltürk vd. 2014: 297). Bu anlamda emeğin yoğun olarak kullanıldı ̆̆ sal ve fiziksel yönden sağlıklı bir şekilde işe gelmeleri, müşteri memnuniyetini sağlayacak olan kaliteli bir hizmetin ön koşulu olabilmektedir. 
Buna karşılık çalışanlar, sektörün kendine özgü özelliklerinden aşırı iş yükü, iş güvencesizliği, uzun ve yorucu çalışma saatleri, işleri yetiştirme stresi ve zaman baskısı gibi nedenlerden dolayı her zaman iş yerine sağlıklı bir şekilde gidemeyebilmektedirler. Çalışanların ruhsal veya fiziksel yönden herhangi bir sağlık problemi yaşamasına rağmen işe gitmesi olarak tanımlanan presentizm kavramı da bu noktada ortaya çıkmaktadır.

Presentizm yarattığ niyle, özellikle yirminci yüzyılın son çeyreğinden itibaren çalışma yaşamında önemli bir kavram olarak gündeme gelmiştir. Çalışanlar açısından presentizm, mevcut hastalığın iyileşmesinin gecikmesi ve sağlık durumunun daha da kötüye gitmesiyle sonuçlanabileceği gibi bir daha çalışma hayatına dönülememesi gibi risklere de yol açabilmektedir (Aydın Tükeltürk vd. 2014: 300). İşletmeler içinse en çok gündeme gelen bu sonuçlar, verimlilik kaybı ve maliyetlerle ilgidir. Öyle ki ABD'de faaliyet gösteren işletmelere, presentizm kaynaklı verimlilik kayıplarının yüklediği ekonomik yıllık maliyetinin 180 milyar \$ civarında olduğu tahmin edilmektedir (Samuel ve Wilson 2007). Bu anlamda presentizm, etkisi gittikçe büyüyen bir sağlık ve üretkenlik riski olarak görülmektedir.

Presentizmin işletmelere yarattı $\breve{g}_{1}$ olumsuz sonuçların azaltılmasında ya da önlenmesinde etkili olabilecek faktörlerden biri, işletme içerisindeki liderlik davranışlarıdır. Konuyla ilişkin alanyazında (Gilbreath ve Karimi 2012; Ekpenyong 2013; Ferreira vd. 2015; Nielsen ve Daniels 2016; Schmid vd. 2017) presentizmin nedenini insan unsuru oluşturduğu için insan odaklı liderlik davranışlarının da presentizm üzerinde azaltıcı rol üstlendiği belirtilmiştir. Bu bağlamda hizmetkâr liderliğin günümüze dek öne sürülen liderlik yaklaşımları içerisinde en yüksek düzeyde insan odaklı davranışları bünyesinde barındırması (Dal 2014: 72), çalışanlara hizmet etme isteği ile en büyük önceliklerinin onlar olması ve örgütsel amaç ve hedefleri ikinci plana atabilmesi (Patterson 2003: 5), bu liderlik yaklaş1mının da presentizm üzerinde etkili olabileceğini düşündürmektedir. Turizm işletmelerine yönelik bu konuyla ilgili herhangi bir çalışmaya rastlan- mamış olması ve otel işletmelerindeki hizmetkâr liderlik davranışlarının çalışanların presentizm yaşama düzeylerini etkileyebileceği düşünüldüğünden bu çalışmanın gerçekleştirilmesi planlanmıştır.

\section{KAVRAMSAL ÇERÇEVE}

\section{Hizmetkâr Liderlik}

Hizmetkâr liderlik kavramı ilk kez 1970 yılında Robert K. Greenleaf (1904-1990) tarafından tanımlanmış ve alanyazına kazandırılmıştır. Greenleaf'ın hizmetkâr liderlik fikrinin ortaya çıkmasında; AT\&T şirketinde çalıştı̆̆ 1 dönemlerde eğitim, geliştirme ve yönetim alanında kazandığ1 tecrübeler (Spears 2010: 26), İncil'de yer alan Hz. İsa'nın örnek davranışları ve Hermann Hesse'nin "Doğuya Yolculuk" (Journey to the East) adlı romanındaki "Leo" karakteri etkili olmuştur (Greenleaf 1977; Ergen 2013). Greenleaf, hizmetkâr liderliği "Hizmetkâr lider öncelikle bir hizmetkârdır. Hizmet etme isteği doğal bir hisle başlar daha sonra birilerine liderlik etmek istediğinizde bilinçli bir tercih haline gelir. Hizmetkâr lider insanların en yüksek öncelikli ihtiyaçlarına hizmet eder" şeklinde tanımlamıştır (Greenleaf 1977 akt. Spears 2010: 26).

Hizmetkâr liderlik yaklaşımında liderler, takipçileri ile birebir iletişim kurmakta ve onların yeteneklerini, ihtiyaçlarını, arzularını ve amaçlarını belirlemeye çalışmaktadır (Liden vd. 2008: 162). Takipçilerinin başarılı olabilmesi için ihtiyaç duyduğu şeyleri sürekli karşılamaya çalışmakta ve takipçilerinden kendisini memnun etmesini istemek yerine onların hayatlarında farklılık yaratmak için çaba göstermektedirler (Vinod ve Sudhakar 2011: 456). Daha kapsamlı bir şekilde, insanlığın gelişimine kendini adayan, şimdiye kadar sadece liderin sahip olduğu hak ve yetkilerin işletme içerisinde bulunan her kademedeki çalışanlar tarafından paylaşılmasını savunan, tüm çalışanlarda ortak değerler inşa edebilen ve işletmelerin yapılandırılması sürecinde stratejik öneme sahip olan bir liderlik yaklaşımıdır (Dinçer ve Bitirim 2007: 68). Page ve Wong'a (2000) göre bir liderlik yaklaşımını yansıttığı kadar, liderliğin grup içerisindeki sorumluluklarına karşı geliştirdiği bir tutumdur. 
Hizmetkâr liderliğin diğer liderlik yaklaşımlarından daha iyi anlaşılabilmesi amacıyla ilgili alanyazını inceleyen araştırmacılar (Page ve Wong 2000; Patterson 2003) belirledikleri hizmetkâr liderlik özelliklerini sınıflandırmışlar ve bunun sonucunda hizmetkâr liderlik modelleri geliştirmişlerdir. Araştırma kapsamında kullanılan Patterson'un (2003) hizmetkâr liderlik modeli "ahlakî sevgi" ile başlamakta ve "hizmet" ile sona ermektedir. Modelin temel yap1 taşını ahlakî sevgi oluşturmaktadır ve liderin alçak gönüllü ve fedakar olmasını sağlamaktadır. Takipçilerine insani olarak değer vermenin göstergelerinden olan bu erdemler ise vizyon oluşturmada ve güven kazanmada etkili olmaktadır. Takipçilerinin güvenini kazanan lider, belirledikleri vizyona ulaşmak amaciyla takipçilerini güçlendirmekte ve böylelikle ahlakî sevgi ile başlayan bu süreç içerisinde lider, takipçilerine hizmet etmektedir.

\section{Presentizm (Edimsizlik)}

Presentizm kavramı Oxford İngilizce Sözlüğü'ne göre, ilk kez Amerikalı yazar Mark Twain tarafından ortaya atılmıştır (Johns 2010: 520). Alanyazında farklı bilgilere rastlansa da 1990'lı yıllarda Cooper'ın presentizm kavramına anlam kazandırdığına dair çalışmalar yoğunluktadır. Cooper'a göre 1990'lı yıllarda dünya genelinde yaşanan ekonomik krizlerin etkisiyle, işletmelerin küçülmeye gitmesi ve bu nedenle çalışanların bir kısmının işsiz kalması, çalışmaya devam edenlerin ise işlerini kaybetmemek için uzun saatler boyunca çalışmak zorunda kalması, presentizmi ayrı bir kavram olarak ortaya çıkarmıştır (Cooper 1998: 313-314; Çoban ve Harman 2012: 161).

İngilizcede "presenteeism" sözcügüyle ifade edilen kavram, "hazır bulunma", "var olma", "orada bulunma" anlamlarına gelen "presence" sözcüğünden türetilmiş ve buradan yola çıkılarak tanımlanmaya çalışılmıştır (Çiftçi 2010: 155). Ulusal alanyazında çalışmaların büyük bir kısminda (Koçoğlu 2007; Çoban ve Harman 2013; Aydın Tükeltürk vd. 2014; Arslaner ve Boylu 2015; Oruç 2015) kavram orijinal hali ile kullanılmış olmakla birlikte işkoliklik (Günbeyi ve Gün- doğdu 2010), hasta iken işe gelme (Ulu vd. 2016), işte var ol(ama)ma (Çiftçi 2010) ve sözde var olma (Yıldız ve Yıldız 2013) gibi karşılıklarla da kullanıldığı görülmektedir. Ontolojik açıdan değerlendirildiğinde çalışanın "var olması" yaptığ 1 iş ile ilintili olarak gerçekleşmektedir. İçinde bulunduğu veri durumdan çıkartıldığında ondan geriye kalan etimolojik anlamda çalışan değil, Sartre'ci bir dille söylemek gerekirse "kendinde varlık" halidir. Bu perspektifle, çalışan, çeşitli nedenlerle işinde edimselleşemediği yani potansiyelini ortaya koyamadığı anda sıradan bir insandır. Buradan yola çıkılarak presentizmin Türkçe karşılığ1 olarak "edimsizlik" kavramının kullanımı önerilebilir.

En temel anlamıyla presentizm, çalışanın iş yerinde fiziksel anlamda bulunmasına karşın zihinsel anlamda varlık gösterememe durumunu ifade etmektedir (Çiftçi 2010: 155). Çalışanların devamsızlık yapması yerine işe gitmesi durumu (Smith 1970) ya da evde dinlemesini veya tedavi edilmesini gerektirecek hastalık durumlarına rağmen işlerine devam etmesi fenomenini anlatmaktadır (Aronsson vd. 2000). Daha kapsamlı bir şekilde presentizm, çalışanların hastalık, yaralanma ve diğer sağlık durumları gibi problemler yaşamalarına rağmen iş yerinde olmaları ve bu problemlerin etkisiyle görevlerini tam manasıyla yerine getirememeleri durumudur ( $\mathrm{D}^{\prime} \mathrm{Abate}$ ve Eddy 2007). Presentizm tanımları incelendiğinde iki farklı eğilimin olduğu anlaşılmaktadır. Birinci eğilim, işletmelerin absenteeism (devamsızlık) sorununu ortadan kaldırmak için, çok keskin ve katı işe devam politikalarına başvurması ve çalışanların çeşitli baskılar (küreselleşme, rekabet, küçülme, zaman, iş güvensizliği) nedeniyle çok uzun saatler boyunca çalışmak zorunda bırakılmasına odaklanılmasıdır. İkinci eğilim ise çal1şanların kendilerini baskı altında hissetmeleri nedeniyle rahatsız olsalar dahi işe gitmeleri ve çalışanların sağlık problemleri (fiziksel, psikolojik) olmasına rağmen iş yerinde bulunma durumları odak noktasıdır (Çoban ve Harman 2013: 167-169). Bu araştırma kapsamında presentizm, "çalışanların hasta iken devamsızlık yapması yerine işe gitmesi ve bunun sonucunda da düşük performans göstermesi" şeklinde ele alınmıştır. 
Ruhsal ve bedensel hastalıkları presentizm için önemli kılan asıl etmen, çalışanların hastalık nedeniyle çalışamayacak durumda olmalarına rağmen işe gitmelerinden kaynaklanmaktadır (Koçoğlu 2007). Yapılan araştırmalarda da (Biron vd. 2006; Eurofound 2012) çalışanların çeşitli hastalıklar yaşamalarına rağmen yine de işlerinin başında olmayı düşündükleri tespit edilmiştir. $\mathrm{Bu}$ durumun nedeni ise çalışanların geçirmekte oldukları hastalıkları ciddi bir problem olarak alg1lamamaları olabileceği gibi işe devam konusunda baskı altında olmaları ya da çeşitli sebeplerden dolayı kendilerini işe gitmek zorunda hissetmelerinden kaynaklanabilmektedir (Firns vd. 2006: 115). Söz konusu bu durumlar içerisinde iş yerine gelen çalışanlar, fiziksel anlamda çalışma ortamında yer alırken zihinsel anlamda varlık gösterememektedirler. Çünkü yaşadıkları bu rahatsızlıklar, iş yerinde tam kapasitesi ile çalışmalarını engellemekte ve dolayısıyla da presentizme maruz kalmaktadırlar (Koçoğlu 2007: 44-45; Oruç 2015: 16).

\section{Otel İşletmelerinde Hizmetkâr Liderlik ve Presentizm ilişkisi}

Otel işletmelerinde görev yapan çalışanların çoğu, müşterilerle yüz yüze ilişki içerisindedir ve müşterilerin memnuniyeti; otelin müşterilerine sunduğu imkanlar kadar, çalışanların kibarlığı, yardımseverliği ve kişisel özelliklerinden de etkilenmektedir (Sü 1999: 6). Bu bakımdan otel işletmelerinde en önemli faktörün insan olduğu göz önünde bulundurulduğunda presentizmin önemi daha iyi anlaşılmaktadır. Ruhsal veya fiziksel yönden hasta olmasına rağmen işe gelen bir otel çalışanı, iş yerindeki görevlerine odaklanamamasından dolayı etkileşim halinde olduğu diğer çalışma arkadaşlarının da motivasyonunu etkileyebilmektedir. Ayrıca bu çalışanın geçirmekte olduğu hastalık türü bulaşıcı ise ilk önce en yakın çalışma arkadaşına daha sonra da otel içerisinde ilgilendiği müşterilere hastalığını bulaştırma ihtimali vardır. Bu durum presentizm sorununun yaratacağı çarpan etkisiyle zamanla işletme geneline yayılarak otel işletmelerinde sunulan hizmetin kalitesinde düşüşler yaşanmasına neden olabilmektedir. Bunun yanında çalışanların yaşadığı herhangi bir sağlık problemi, psikolojik du- rumlarına etki edebilmekte ve bu durum müşteri ilişkilerine yansiyarak müşteri memnuniyetsizliğini de beraberinde getirmektedir. Belirtilen bu durumlar, otel işletmelerinde sağlıklı çalışanlara ihtiyaç duyulduğunu ve hastayken işe devam edilmesinin olumsuz sonuçlara yol açabileceğini göstermektedir.

Presentizmin oluşmasında etkili olan faktörlerden biri de işletme içerisindeki liderlik davranışları olmaktadır. Liderlik davranışlarının presentizm üzerindeki etkilerini belirlemek amaciyla yapılan çalışmalar incelendiğinde; yerli alanyazında, liderlik tarzının presentizm üzerindeki etkisini belirlemeye yönelik herhangi bir çalışmaya rastlanmamış olup yabancı alanyazında ise bu iki kavramı birlikte ele alan sınırlı sayıda (Gilbreath ve Karimi 2012; Ekpenyong 2013; Ferreira vd. 2015; Nielsen ve Daniels 2016; Schmid vd. 2017) çalışma bulunmaktadır. Gilbreath ve Karimi (2012), otoriter liderlik davranışlarının presentizmi pozitif yönde, demokratik liderlik davranışlarının ise negatif yönde etkilediğini tespit ederken Ekpenyong (2013), presentizm ile etkileşimci liderlik tarzı arasında istatiksel olarak anlamlı bir ilişki olmadığını ancak presentizm ile tam serbesti tanıyan liderlik tarzı arasında pozitif yönde, dönüşümcü liderlik tarzı arasında ise negatif yönde bir ilişki olduğunu belirlemiştir. Nielsen ve Daniels de (2016) dönüşümcü liderlerin, presentizm sorununu yüksek düzeyde yaşayan çalışanları, hastalığa bağlı devamsızlık yapmaya teşvik edebilecek bir grup iklimi oluşturması sayesinde çalışanların işletme içerisindeki presentizm davranışlarının önemli ölçüde azaldığı$\mathrm{n} ı$ ifade etmişlerdir. Bununla birlikte Ferreira ve arkadaşları (2015) lider üye değişimi (LMX) ile presentizm iklimi arasında negatif yönlü bir ilişki olduğunu; Schmid ve arkadaşları (2017) ise algılanan destekleyici liderlik davranışlarının hem presentizmle hem de işe devamsızlıkla negatif yönde ve anlamlı bir ilişkisinin olduğunu tespit etmişlerdir.

Konuyla ilgili yapılan çalışmalardan da anlaşılacağı üzere, çalışmaların büyük bir çoğunluğunda liderlik tarzlarının presentizm üzerindeki etkisi görgül kanıtlarla da doğrulanmıştır. Buna göre konuyla ilgili çalışma yapan araştırmacılar 
LMX, dönüşümcü, destekleyici veya demokratik lider gibi beşeri ilişkileri iyi olan bir liderle çalışanların hastayken işe gitmesine bağlı olarak yaşadı ̆̆ 1 presentizm sorununun, çalışan-lider arasındaki iletişimin kuvvetli olmasından ve bu liderlik tarzlarının insan odaklı davranışları bünyesinde barındırmasından dolayı önemli ölçüde azaldığını ifade etmişlerdir. Hizmetkâr liderliğin liderlik teorileri içerisinde en yüksek düzeyde insan odaklı davranışları bünyesinde barındırması ve bu nedenle otel işletmelerinde çalışanların presentizm sorunu yaşama düzeylerini etkileyebileceği düşünüldüğünden aşağıdaki hipotez belirlenmiştir:

Hipotez $\left(\mathrm{H}_{1}\right)$ : Beş yıldızlı otel işletmelerinde çalışanların hizmetkâr liderlik algılarının presentizm düzeyleri üzerinde negatif yönde bir etkisi vardır.

Aynı zamanda hizmetkâr liderlik boyutlarının herbirinin çalışanların presentizm düzeyi üzerinde etkili olduğu düşünüldüğünden şu hipotez belirlenmiştir:

Hipotez $\left(\mathrm{H}_{2}\right)$ : Beş yıldızlı otel işletmelerinde çalışanların hizmetkâr liderlik algılarını oluşturan boyutların (sevgi, güçlendirme, vizyon, güven ve alçakgönüllülük) presentizm düzeyleri üzerinde negatif yönde bir etkisi vardır.

\section{YÖNTEM}

Araştırmanın amacı, Frigya bölgesinde faaliyet gösteren beş yıldızlı otel işletmelerindeki hizmetkâr liderlik davranışlarının çalışanların presentizm düzeyleri üzerinde etkisi olup olmadığını belirlemektir. Nedensellik ilişkisi tasarımında oluşturulan araştırmanın modeli Şekil 1'd e sunulmuştur. Devamında araştırmada kullanılan veri toplama araçları, evren ve örneklemi ile verilerin analizine ilişkin bilgilere de yer verilmiştir.

\section{Veri Toplama Aracı}

Araştırma, nicel araştırma desenine göre yürütülmüştür. Veri toplamada, çalışanların hizmetkâr liderliğe ilişkin görüşleri ile presentizm düzeylerinin belirlenmesi amaciyla anket tekniğinden yararlanılmıştır. Araştırmada kullanılan anket üç bölümden oluşmaktadır. Anketin ilk bölümünde

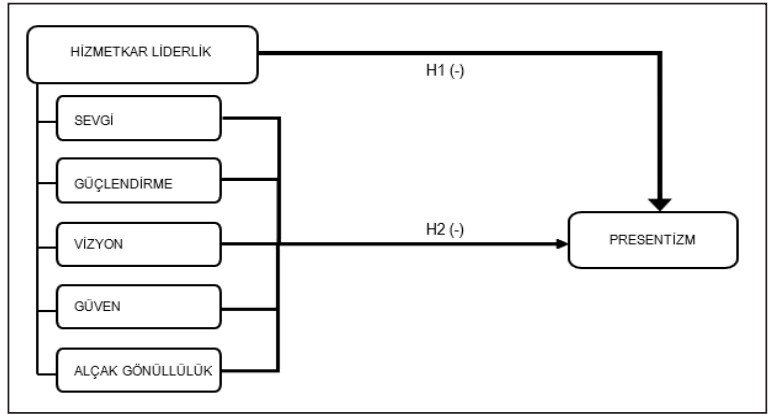

Şekil 1. Araştırmanın Modeli

Dennis ve Bocernea (2005) tarafından geliştirilen ve Ergen (2013) tarafından dil eşdeğerlilikleri sağlanarak Türkçeye çevrilen hizmetkâr liderlik ölçeği kullanılmıştır. Anketin ikinci bölümünde Koopman ve arkadaşları (2002) tarafından geliştirilen, "Stanford Presenteeism Ölçeği" nin (SPS) Baysal (2012) tarafından Türkçeye uyarlanmış biçimi kullanılmıştır. Her iki ölçek de 5'li Likert ölçeğine göre derecelendirilmiştir. Son bölümde ise otel çalışanların demografik özelliklerini (bireysel ve çalışma yaşamına ilişkin) belirlemeye yönelik kapalı uçlu sorulara yer verilmiştir.

\section{Evren ve Örneklem}

Araştırmanın evrenini Frigya bölgesinde faaliyet gösteren Turizm İşletme Belgesine sahip beş yıldızlı otel işletmelerinin çalışanları oluşturmaktadır. Araştırmanın Frigya bölgesinde yürütülmesinde, bölgenin bilinirliğinin ve bir turistik destinasyon olarak algılanılmasının istenilen düzeyde olmaması ve bölgeye yönelik olarak yapılacak bilimsel bir çalışmanın bölgeye katkı sağlayabileceği düşüncesi etkili olmuştur. Beş yıldızlı otellerde uygulanmasının nedeni ise diğer otel işletmelerine göre daha çok profesyonel yöneticileri bünyesinde bulundurmaları ve yönetici-çalışan ilişkilerinin ilgili işletmelerde daha yoğun yaşanacağı varsayımıdır.

Kültür ve Turizm Bakanlığ tarafından yayınlanan Türkiye Turizm Stratejisi (2023) ve Eylem Planı'na (2007-2013) göre, Frigya bölgesinin s1nırları içerisinde; Uşak, Afyonkarahisar, Kütahya, Eskişehir ve Ankara illeri yer almaktadır. Beş ilin Îl Kültür ve Turizm Müdürlükleri'nden temin edilen verilere göre, toplam 37 adet (Ankara: 24; Afyonkarahisar: 10; Eskişehir: 3) beş 
yıldızlı otel işletmesi ve bu otel işletmelerine ait 7921 oda (Ankara: 4810; Afyonkarahisar: 2646; Eskişehir: 465) bulunmaktadır. Kültür ve Turizm Bakanlığının 2007 yılı verilerine göre, Türkiye'de beş yıldızlı bir otel işletmesinde oda başına düşen çalışan sayısı 1,18'dir (Pelit 2008: 130). Oda sayıları dikkate alınarak ve $7921 \times 1,18$ formülünden yola çıkarak araştırmanın evreni 9347 olarak hesaplanmıştır. Ancak zaman ve maliyet gibi nedenlerden dolayı evrenin tamamına ulaşılmasının zor olacağ 1 düşüncesiyle örneklem alma yoluna gidilmiştir. Yazıcıŏglu ve Erdoğan'ın (2007: 70) evreni temsil edebilecek örneklemin sayısını tespit etmek amaciyla geliştirdikleri formül kullanılarak, yüzde 99 güven aralığında örneklem sayısı (n) 622 bulunmuştur. Kota örneklem yöntemine göre, araştırma alanında yer alan çalışanlar evrende var oldukları oranda illere göre temsil edilmiştir. Buna göre 2017 yılının 15 Mayıs-15 Haziran tarihleri arasında toplam evrenin yüzde 61'ini temsil eden Ankara iline 393, yüzde 33'ünü temsil eden Afyonkarahisar iline 247, yüzde 6's1$\mathrm{n} 1$ temsil eden Eskişehir iline ise 52 adet anket uygulanmış ve toplamda 692 adet anket analize tabi tutulmuştur.

\section{Verilerin Analizi}

Araştırma kapsamında analize tabi tutulan anketlerden elde edilen veriler, sosyal bilimler için kullanılan istatistik paket programina aktarılmıştır. Daha sonra verilerin istatistiksel analizlere uygun olup olmadığını belirlemek amacıyla Cronbach Alpha güvenirlik testi gerçekleştirilmiştir. Verilerin güvenilirlik analizinden sonra araştırmaya katılan çalışanların demografik özelliklerinin analizinde yüzde ve sıklık teknikleri kullanılmıştır. Bununla birlikte çalışanların hizmetkâr liderlik algılarının presentizm düzeyleri üzerindeki etkisini belirlemek amaciyla korelasyon, basit ve çoklu doğrusal regresyon analizleri yapılmıştır.

\section{BULGULAR VE TARTIŞMA}

\section{Araştırmada Kullanılan Ölçeklerin Güvenilirlikleri}

Araştırmada kullanılan ölçeklere ilişkin güvenirlik katsayıları, Cronbach's Alpha değerleri ile belirlenmiş ve Tablo 1'de sunulmuştur.
Tablo 1. Ölçeklere İlişkin Güvenirlik Katsayıları

\begin{tabular}{lrr}
\hline Ölçekler & $\begin{array}{r}\text { Cronbach's Alpha } \\
\text { Katsayıları }\end{array}$ & $\begin{array}{r}\text { Madde } \\
\text { Sayısı }\end{array}$ \\
\hline Hizmetkar Liderlik Genel & 0,956 & 25 \\
\hline Sevgi & 0,893 & 5 \\
\hline Güçlendirme & 0,891 & 5 \\
\hline Vizyon & 0,855 & 5 \\
\hline Güven & 0,877 & 5 \\
\hline Alçak Gönüllülük & 0,894 & 5 \\
\hline Presentizm Genel & 0,720 & 6 \\
\hline
\end{tabular}

Hizmetkâr liderlik ölçeğine ilişkin genel güvenirlik katsayısı 0,956 olarak hesaplanmış ve alt boyutların tamamının $0,85^{\prime}$ in üzerinde olduğu saptanmıştır. Presentizm ölçeği 0,72 olarak hesaplanmıştır. Ölçeklerin güvenilir olması için ise Cronbach's Alpha değerlerinin en az 0,70 olması gerekmektedir. Bu sonuçlara göre, araştırmada kullanılan ölçeklerinin güvenilir oldukları söylenebilir $(\alpha>0,70)$.

\section{Katılımcılara İlişkin Bulgular}

Örneklem içerisinde yer alan otel işletmeleri çalışanlarının bireysel ve çalışma yaşamına ilişkin özellikleri Tablo 2'de gösterilmektedir.

Tablo 2 incelendiğinde, çalışanların; yüzde $55,8^{\prime}$ inin erkek olduğu, büyük çoğunluğunun (yüzde 88,6) 39 yaş ve altı genç ve orta yaş aralığına sahip çalışanlardan oluştuğu, yarısından fazlasının (yüzde 55,1) evli ve büyük kısmının da lise (yüzde 43,3) ve önlisans/lisans (yüzde 34) düzeyinde eğitim aldıkları görülmektedir. Bu bulgular otel işletmelerinde kadınların da erkekler kadar iş yaşamında aktif olarak yer almasıyla, aşırı iş yüküne bağlı olarak fiziksel ve zihinsel gücün yoğun olarak kullanılması nedeniyle daha çok genç çalışanların istihdam edilmesiyle, evlilerin bekarlara göre daha düzenli bir hayata sahip olabileceği düşüncesiyle ve eğitimli personelin müşterilerle daha iyi iletişim kurabilmesiyle ilişkilendirilebilir ve istihdam edilen personel konusunda etkili olmuş olabilir.

Çalışma yaşamına ilişkin özellikleri gösteren bulgularda, çalışılan bölümlerin dengeli bir şekilde dağıldığı, büyük bir kısmının (yüzde 77) işletme içerisinde hiçbir yönetsel görevi olmayan 
Algılanan Hizmetkâr Liderliğin Presentizm (Edimsizlik) Üzerindeki Etkisi: Frigya Bölgesi

Tablo 2. Katılımcılara İlişkin Bulgular

\begin{tabular}{|c|c|c|c|}
\hline \multicolumn{2}{|c|}{ Bireysel Değişkenler } & \multirow{2}{*}{$\begin{array}{c}f \\
306\end{array}$} & \multirow{2}{*}{$\frac{\%}{44,2}$} \\
\hline & Kadın & & \\
\hline Cilisiyel & Erkek & 382 & 55,8 \\
\hline \multirow{5}{*}{ Yaş Grubu } & 20 yaş altı & 73 & 10,5 \\
\hline & $20-29$ yaş arası & 315 & 45,6 \\
\hline & $30-39$ yaş arası & 225 & 32,5 \\
\hline & 40-49 yaş arası & 52 & 7,5 \\
\hline & 50 yaş ve üzeri & 27 & 3,9 \\
\hline \multirow{2}{*}{ Medeni Durum } & Bekâr & 311 & 44,9 \\
\hline & Evli & 381 & 55,1 \\
\hline \multirow{4}{*}{ Eğitim Durumu } & İlköğretim & 125 & 18,1 \\
\hline & Lise & 300 & 43,3 \\
\hline & Önlisans/Lisans & 235 & 34 \\
\hline & Lisansüstü & 32 & 4,6 \\
\hline
\end{tabular}

Toplam $(f)=692$ çalışan

\begin{tabular}{|c|c|c|c|}
\hline \multicolumn{2}{|c|}{ Çalışma Yaşamına İlişkin Değişkenler } & $f$ & $\%$ \\
\hline \multirow{6}{*}{ Çalışılan Bölüm } & Önbüro & 120 & 17,3 \\
\hline & Kat hizmetleri & 160 & 23,1 \\
\hline & Yiyecek-İecek & 156 & 22,5 \\
\hline & Muhasebe & 31 & 4,5 \\
\hline & Mutfak & 107 & 15,5 \\
\hline & Diğer & 118 & 17,1 \\
\hline & Genel müdür yardımcısı & 15 & 2,2 \\
\hline Çalışılan & Departman müdürü & 49 & 7,1 \\
\hline \multirow[t]{3}{*}{ Pozisyon } & Şef & 95 & 13,7 \\
\hline & Diğer Personel (Çalışan) & 533 & 77 \\
\hline & 1 yıldan az & 102 & 14,8 \\
\hline Turizm & $1-5 \mathrm{yıl}$ arası & 261 & 37,7 \\
\hline Sektöründe & 6-10 yıl arası & 216 & 31,2 \\
\hline \multirow[t]{3}{*}{ Çalışma Süresi } & $11-15$ yıl arası & 65 & 9,4 \\
\hline & 16 yll ve üzeri & 48 & 6,9 \\
\hline & 1 yıldan az & 316 & 45,7 \\
\hline Bulundukları & $1-5$ yıl arası & 270 & 39 \\
\hline Oteldeki & 6-10 yıl arası & 59 & 8,5 \\
\hline \multirow[t]{2}{*}{ Çalışma Süresi } & $11-15$ yıl arası & 22 & 3,2 \\
\hline & 16 yıl ve üzeri & 25 & 3,6 \\
\hline
\end{tabular}

derlik algıları ile presentizm düzeyleri arasındaki ilişki, korelasyon analizi ile belirlenmiş ve değişkenler arasındaki ilişkiler Pearson korelasyon katsayısı ile hesaplanmıştır. Tablo 3'teki bulgulara göre, hizmetkâr liderliğin tüm alt boyutları ile presentizm arasında istatistiksel olarak anlam$l_{1}(p<0,001)$ ve orta düzeyde bir ilişkinin olduğu görülmektedir. Korelasyon katsayıları incelendiğinde, diğer alt boyutlara oranla presentizm ile negatif yönde en yüksek düzeyde ilişkisi olan hizmetkâr liderlik alt boyutunun güçlendirme $(r=-494)$ olduğu görülmektedir. Güçlendirmeyi ise sırasıyla sevgi ( $r=-467)$, güven $(r=-453)$, alçak gönüllülük ( $\mathrm{r}=-433)$ ve vizyon ( $\mathrm{r}=-388)$ alt boyutları takip etmektedir.

Genel olarak hizmetkâr liderlik ile presentizm arasında ise 0,001 anlamlılık düzeyinde önemli 
Necip Özdemir - Esra Gül Yılmaz

Tablo 3. Hizmetkâr Liderlik ile Presentizm Arasındaki İlişkiyi Belirlemeye Yönelik Korelasyon Katsayıları

\begin{tabular}{|c|c|c|c|c|c|c|c|c|c|c|}
\hline & $\bar{x}$ & s.s. & & 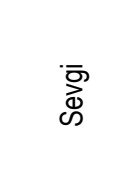 & 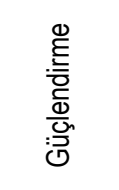 & $\stackrel{\bar{N}}{\stackrel{N}{>}}$ & : & 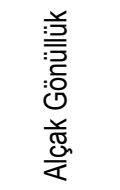 & 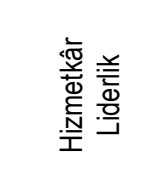 & 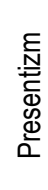 \\
\hline Sevgi & 3,36 & 1,09 & $\begin{array}{l}\mathrm{r} \\
\mathrm{p}\end{array}$ & 1 & & & & & & \\
\hline Güçlendirme & 3,35 & 1,04 & $\begin{array}{l}r \\
p\end{array}$ & $\begin{array}{l}0,761^{\text {*t* }} \\
0,000\end{array}$ & 1 & & & & & \\
\hline Vizyon & 3,15 & 1,04 & $r$ & $\begin{array}{l}0,559^{* * *} \\
0,000\end{array}$ & $\begin{array}{l}0,694^{*+*} \\
0,000\end{array}$ & 1 & & & & \\
\hline Güven & 3,67 & 1,03 & r & $\begin{array}{l}0,619^{\text {*** }} \\
0,000\end{array}$ & $\begin{array}{l}0,631^{\star * \star} \\
0,000\end{array}$ & $\begin{array}{l}0,481^{\text {*t+k }} \\
0,000\end{array}$ & 1 & & & \\
\hline Alçak Gönüllük & 3,32 & 1,09 & $r$ & $\begin{array}{l}0,639^{*+*} \\
0,000\end{array}$ & $\begin{array}{l}0,659^{+*+*} \\
0,000\end{array}$ & $\begin{array}{l}0,591^{\text {*t*k }} \\
0,000\end{array}$ & $\begin{array}{l}0,600^{\text {**** }} \\
0,000\end{array}$ & 1 & & \\
\hline Hizmetkâr Liderlik & 3,37 & 0,88 & $r$ & $\begin{array}{l}0,858^{\text {**** }} \\
0,000\end{array}$ & $\begin{array}{l}0,895^{\text {t+* }} \\
0,000\end{array}$ & $\begin{array}{l}0,793^{\text {*t* }} \\
0,000\end{array}$ & $\begin{array}{l}0,795^{\text {*** }} \\
0,000\end{array}$ & $\begin{array}{l}0,838^{*+*} \\
0,000\end{array}$ & 1 & \\
\hline Presentizm & 2,77 & 0,70 & $r$ & $\begin{array}{l}-0,467^{+ \text {tox }} \\
0,000\end{array}$ & $\begin{array}{l}-0,494^{*+*} \\
0,000\end{array}$ & $\begin{array}{l}-0,388^{*+* x} \\
0,000\end{array}$ & $\begin{array}{l}-0,453^{\text {tot }} \\
0,000\end{array}$ & $\begin{array}{l}-0,433^{\text {t*t }} \\
0,000\end{array}$ & $\begin{array}{l}-0,535^{+* * x} \\
0,000\end{array}$ & 1 \\
\hline
\end{tabular}

bir ilişki bulunmuştur. Korelasyon katsayısı r=0,535 olarak hesaplanmış ve negatif yönlü orta düzeyli bir ilişkinin olduğu tespit edilmiştir. $\mathrm{Bu}$ bulguya göre, çalışanların hizmetkâr liderlik algıları $(x-=3,37)$ arttıkça presentizm düzeylerinin de $(x-=2,77)$ buna bağlı olarak azalacağ ifade edilebilir. Konuyla ilgili yapılan çalışmalarda farklı liderlik tarzları ele alınmış olsa da insan odaklı liderlik davranışları bünyesinde barındıran dönüşümcü liderliğin (Ekpenyong 2013), LMX'in (Ferreira vd. 2015) ve destekleyici liderliğin de (Schmid vd. 2017) presentizmle negatif yönde ilişkili olduğu ortaya koyulmuştur. Bu doğrultuda, en yüksek düzeyde insan odaklı davranışları bünyesinde barındıran hizmetkâr liderlik ile presentizm arasında negatif yönlü bir ilişkinin tespit edilmesi, konuya ilişkin alanyazına göre beklenen bir sonuç olarak görülebilir.

Tablo 4'te hizmetkâr liderliğin genel olarak presentizm üzerindeki etkisini belirlemeye yöne- lik basit doğrusal regresyon analizine ilişkin sonuçlara yer verilmiştir.

Tablodaki sonuçlara göre hizmetkâr liderliğin presentizm üzerindeki etkisini belirlemeye yönelik regresyon modeli şu şekilde kurulabilir.

Presentizm $=4,198-0,423 x$ Hizmetkâr Liderlik

Kurulan söz konusu model incelendiğinde, hizmetkâr liderlikte gerçekleşen her 1 (bir) birimlik artışın, presentizmde 0,423 değerinde bir azalışa neden olacağını göstermektedir. Diğer bir anlatımla, çalışanların hizmetkâr liderlik algıları, presentizm düzeylerini negatif yönde etkilemektedir. Bu doğrultuda, araştırma kapsamında belirlenen " $\mathrm{H}_{1}$ " hipotezi kabul edilmiştir. Liderlik tarzlarının presentizm üzerindeki etkisini belirlemeye yönelik ilgili alanyazında sadece Gilbreath ve Karimi'nin (2012) çalışmasına rastlanmış ve otoriter liderlik davranışlarının presentizmi pozitif yönde $(\beta=0,50)$, demokratik liderlik dav- 
Algılanan Hizmetkâr Liderliğin Presentizm (Edimsizlik) Üzerindeki Etkisi: Frigya Bölgesi

Tablo 4. Hizmetkâr Liderliğin Presentizm Üzerindeki Etkisi

\begin{tabular}{|c|c|c|c|c|c|c|c|c|c|}
\hline & \multirow{3}{*}{ Model } & \multirow{2}{*}{\multicolumn{2}{|c|}{$\begin{array}{c}\text { Standardize Edilmemiş } \\
\text { Katsayılar }\end{array}$}} & \multirow{3}{*}{$\begin{array}{c}\text { Standardize Edilmiş } \\
\text { Katsayılar } \\
\text { Beta }\end{array}$} & \multirow{3}{*}{$t$} & \multirow{3}{*}{ Sig. } & \multirow{3}{*}{$\begin{array}{c}F \\
\text { Değeri }\end{array}$} & \multirow{3}{*}{ Düzeltilmiş $R^{2}$} & \multirow{3}{*}{ Sig. } \\
\hline & & & & & & & & & \\
\hline & & $B$ & S.S. & & & & & & \\
\hline \multirow[b]{2}{*}{1} & Sabit & 4,198 & 0,089 & --- & 47,351 & 0,000 & \multirow[b]{2}{*}{276,330} & \multirow[b]{2}{*}{0,285} & \multirow[b]{2}{*}{0,000} \\
\hline & $\begin{array}{l}\text { Hizmetkâr } \\
\text { Liderlik }\end{array}$ & $-0,423^{\star \star *}$ & 0,025 & $-0,535$ & $-16,623$ & 0,000 & & & \\
\hline
\end{tabular}

Sig.: anlamlılık düzeyi (p), ${ }^{* * *}$ p<0,001 düzeyinde ilişkiler anlamlıdır, n: 692

ranışlarının ise presentizmi negatif yönde ( $\beta=-$ $0,33)$ etkilediği sonucuna ulaşılmıştır. Bu sonuçlara göre sert üsluba sahip liderler tarafından gösterilen katı yönetim tarzlarının çalışanlardaki presentizm sorununu artırabileceği; çalışanlarına değer veren, onları destekleyen ve karar alma süreçlerine katılmalarını sağlayan liderlik davranışlarının ise presentizmi azaltabileceği ifade edilmiştir. Buna göre Gilbreath ve Karimi'nin (2012) araştırma sonuçları, çalışmanın temel hipotezine yönelik elde edilen bulguyu destekler niteliktedir.

Hizmetkâr liderliğin alt boyutlarının presentizm üzerindeki etkisinin çoklu doğrusal regresyon analizi sonuçları Tablo 5'te sunulmuştur.
Tablodaki bulgular incelendiğinde güçlendirme, güven ve sevgi boyutlarının presentizm üzerinde anlamlı bir etkisi $(\mathrm{p}<0,05)$ olduğu görülürken, alçak gönüllülük ( $\mathrm{p}=0,051 ; \mathrm{p}>0,05)$ ve vizyon boyutlarının ( $p=0,372 ; p>0,05)$ presentizm üzerinde anlamlı bir etkisi olmadığı anlaşılmaktadır. Bu bilgiler dahilinde, hizmetkâr liderliğe ilişkin alt boyutlarının presentizm üzerindeki etkisini belirlemeye yönelik matematiksel bir regresyon modeli şu şekilde kurulabilir.

Presentizm $=4,211-0,134 x$ Güçlendirme - 0,119 $x$ Güven - 0,081 x Sevgi

Yukarıdaki modelde B değerlerine karşılık gelen regresyon katsayıları incelendiğinde, model üzerinde negatif yönde en çok etkisi bulunan

Tablo 5. Hizmetkâr Liderliğin Alt Boyutlarının Presentizm Üzerindeki Etkisi

\begin{tabular}{|c|c|c|c|c|c|c|c|c|}
\hline \multirow[t]{2}{*}{$\begin{array}{l}\text { Bağımsız } \\
\text { Değişkenler }\end{array}$} & \multicolumn{2}{|c|}{$\begin{array}{c}\text { Standardize Edilmemiş } \\
\text { Katsayılar }\end{array}$} & \multirow{2}{*}{$\begin{array}{c}\begin{array}{c}\text { Standardize } \\
\text { Edilmiş Katsayılar }\end{array} \\
\text { Beta }\end{array}$} & \multirow[t]{2}{*}{$t$} & \multirow[t]{2}{*}{ Sig. } & \multirow[t]{2}{*}{ F Değeri } & \multirow[t]{2}{*}{$\begin{array}{c}\text { Düzeltilmiş } \\
R^{2}\end{array}$} & \multirow[t]{2}{*}{ Sig. } \\
\hline & $B$ & S.S & & & & & & \\
\hline Sabit & 4,211 & 0,091 & --- & 46,211 & 0,000 & \multirow{6}{*}{56,611} & \multirow{6}{*}{0,287} & \multirow{6}{*}{0,000} \\
\hline Sevgi & $-0,081^{*}$ & 0,034 & $-0,125$ & $-2,377$ & 0,018 & & & \\
\hline Güçlendirme & $-0,134^{\star *}$ & 0,040 & $-0,198$ & $-3,326$ & 0,001 & & & \\
\hline Vizyon & $-0,028$ & 0,031 & $-0,041$ & $-0,894$ & 0,372 & & & \\
\hline Güven & $-0,119^{* * *}$ & 0,030 & $-0,175$ & $-3,937$ & 0,000 & & & \\
\hline Alçak Gönüllük & $-0,059$ & 0,030 & $-0,093$ & $-1,957$ & 0,051 & & & \\
\hline
\end{tabular}

Sig.: anlamlıık düzeyi (p), ${ }^{*} p<0,05 ;{ }^{* *} p<0,01 ;{ }^{* * *} p<0,001$ düzeyinde ilişkiler anlamlıdır, n: 692 
boyutların güçlendirme, güven ve sevgi olduğu görülmektedir. Bu doğrultuda, araştırma kapsaminda belirlenen "H2" hipotezi kısmen kabul edilmiştir. Bu sonuçlara göre, Frigya bölgesinde faaliyet gösteren beş yıldızlı otel işletmeleri çalışanlarının presentizme daha az oranda maruz kalmaları; birlikte çalıştıkları hizmetkâr liderlerin onları sürekli kontrol etmek yerine yetki ve sorumluluk vererek işletme içerisinde daha da güçlendirmesiyle, sevgi dolu davranışlar sergileyerek onların zor zamanlarında destek olmasıyla ve işletme genelinde güvene dayalı bir örgüt kültürü oluşturmasıyla etkili olduğu söylenebilir.

\section{SONUÇ VE ÖNERILER}

Bu çalışma otel çalışanlarının hizmetkâr liderlik algılarının presentizm düzeyleri üzerindeki etkisini belirlemek amaciyla yürütülmüştür. Araştırma sonuçlarına göre, hizmetkâr liderlik hem genel olarak hem de sevgi, güçlendirme ve güven boyutlarında presentizm üzerinde azaltıcı bir etkiye sahiptir. Bu bakımdan değerlendirildiğinde insan odaklı liderlik davranışlarının örgütlerde presenteizm düzeyini azaltmak konusunda etkili olduğuna ilişkin çalışmaların (Gilbreath ve Karimi 2012; Ekpenyong 2013; Ferreira vd. 2015; Nielsen ve Daniels 2016; Schmid vd. 2017) sonuçları ile örtüşmektedir. Chung vd. (2010) otel işletmelerindeki hizmetkâr liderlerin çalışanlarına zor zamanlarında destek olmasından dolayı lider-çalışan arasındaki ilişkinin daha güçlü olduğunu belirtmişlerdir. Liderlerinin kendisine her konuda destek olduğuna inanan otel çalışanları herhangi bir sağlık problemi yaşadığında rahatsızlığını gizleme gereği duymayacaktır. Arslaner ve Boylu (2015) tarafından da ifade edildiği gibi presentizmin azaltılmasında liderlere önemli görevler düşmektedir. Bu kapsamda sektör yöneticileri çalışma saatlerini düzenlemeli, çalışanların hastalık izni kullanımında esnek davranmalı, iş kaybetme ve ücret kesintisi korkusu azaltılmalı ve stres, çatışma gibi ruhsal rahatsızlıklara neden olacak faktörlerle mücadele etmelidirler.

Çalışmadan elden edilen diğer sonuca göre, çalışanların hizmetkâr liderlik algılarının genellikle olumlu olmakla birlikte orta düzeye yakın olduğu tespit edilmiştir. Oysa hizmetkâr lider- lik çalışanların örgüte olan güvenini, bağlıl1ğını ve performanslarını artıracağından, emek yoğun faaliyet gösteren otel işletmeleri için en uygun liderlik yaklaşımlarından biridir (Ergen 2013). Otel işletmelerinde sunulan hizmet soyut olduğu için ve insan aracılığıyla sunulduğu için çalışanların ihtiyaç ve isteklerinin ön plana alınması önemlidir. Bu nedenle liderlerin takipçilerini dinlemeleri, kişisel gelişimlerine önem vermeleri, yani bir anlamda onlara hizmet etmeleri önemlidir (Çevik ve Akoğlan Kozak 2010: 85). Bu noktada çalışanların presentizm yaşamalarından kaynaklı otel işletmelerinde yaşanabilecek verimlilik kayıplarını azaltmak isteyen yöneticilerin, hizmetkâr liderlik davranışlarını çalışanlara daha yoğun hissettirmeleri gerekmektedir. Bunu sağlamak üzere ise çalışanların ruhsal veya fiziksel rahatsızlıkları başta olmak üzere yaşadıkları herhangi bir sorun karşısında liderlerin içten, samimi ve sevgi dolu davranışlar sergileyerek onlara destek olmaları, birlikte çalıştıkları arkadaşlarının herhangi bir rahatsızlığında onların yerine rahatllkla görev alabilmeleri için liderlerin onlara çapraz eğitim vererek işletme içerisindeki farklı bölümlerde de güçlendirmeleri, hastalık izni alındığında çalışanların liderlerine güvenmesinden dolayı işine son verilmeyeceğini bilmesi ve otel işletmelerinde güvene dayalı ilişkilerin kurulduğu bir çalışma ortamı sağlamaları yararlı olacaktır.

Araştırmanın sektöre olan katkılarının yanında presentizm kavramının turizm sektöründe sınırlı sayıda çalışılmış olması ve kavramı hizmetkâr liderlik ile ilişkilendiren çalışmaya ilgili alanyazında rastlanmaması nedeniyle öncü bir çalışma niteliğinde olması, ilgili alanyazına da katkı sağlayabileceğini düşündürmektedir. Bununla birlikte gerçekleştiren bu araştırma Frigya bölgesi ile sinırlıdır. Bu bağlamda hizmetkâr liderliğin presentizm üzerinde etkisinin olup olmadığ 1 ilerleyen dönemlerde farklı bölgelerde gerçekleştirilecek çalışmalar ile tekrar sınanabilir ve elde edilecek sonuçlar araştırmanın sonuçlarıyla karşılaştırılabilir. Araştırma Frigya bölgesinde faaliyet gösteren farklı sınıf ve türdeki konaklama işletmelerinde, yiyecek işletmelerinde veya seyahat işletmelerinde tekrarlanabilir. 


\section{KAYNAKÇA}

Aronsson, G., Gustafsson, K. ve Dallner, M. (2000). Sick But Yet at Work: An Empirical Study of Sickness Presenteeism, Journal of Epidemiology and Community Health, 54(7): 502-509.

Arslaner, E. ve Boylu, Y. (2015). İş Hayatında Presenteeism: Otel İşletmeleri Açısından Bir Değerlendirme, Journal of Business Research-Turk/İşletme Araştırmaları Dergisi, 7(4): 123-136.

Aydın Tükeltürk, Ş., Şahin, D. ve Yılmaz, A. İ. (2014). Turizm İşletmelerinde Presenteeism (İşte Var Olamama). İçinde Ş. Aydın Tükeltürk, N. Şahin Perçin ve B. Güzel (Editörler), Turizm İşletmelerinde Çalışan İlişkileri Yönetimi (ss. 281-302). Ankara: Detay Yayıncılık.

Baysal, İ. A. (2012). Presenteeism (İşte Varolmama Sorunu) İle Örgütsel Bağlllık Arasındaki İlişski: Adnan Menderes Üniversitesi Akademik Personeli Üzerinde Bir Uygulama. (Basılmamış Yüksek Lisans Tezi). Aydın: Adnan Menderes Üniversitesi İşletme Ana Bilim Dalı.

Biron, C., Brun, J., Ivers, H. ve Cooper, C. L. (2006). At Work but Ill: Psychosocial Work Environment and WellBeing Determinants of Presenteeism Propensity, Journal of Public Mental Health, 5(4): 26-37.

Cooper, C. L. (1998). The Changing Nature of Work [1], Community Work and Family, 1(3): 313-317.

Çevik, S. ve Akoğlan Kozak, M. (2010). Değişim Yönetiminde Dönüşümcü Liderlik ve Hizmetkâr Liderlik. 11. Ulusal Turizm Kongresi (ss 80-87). Kuşadası.

Çiftçi, B. (2010). İşte Var Ol(ama)ma Sorunu ve İşletmelerin Uygulayabileceği Çözüm Önerileri, Çalışma ve Toplum Dergisi, 1(24): 153-174.

Çoban, Ö. ve Harman, S. (2012). Presenteeism: Nedenleri, Yarattığ1 Örgütsel Sorunlar ve Çözüm Önerileri Üzerine Bir Alanyazın Taraması, Selçuk Üniversitesi İktisadi ve İdari Bilimler Fakültesi Sosyal ve Ekonomik Araştırmalar Dergisi, 12(23): 157-178.

Chung, J. Y., Jung, C. S., Kyle, G. T. ve Petrick, J. F. (2010). Servant Leadership and Procedural Justice in the U.S. National Park Service: The Antecedents of Job Satisfaction, Journal of Park and Recreational Administration, 28(3), 1-15.

D'Abate, C. P. ve Eddy, E. R. (2007). Engaging in Personal Business on the Job: Extending the Presenteeism Construct, Human Resource Development Quarterly, 18(3): 361-383.

Dal, L. (2014). Hizmetkâr Liderlik ile Lider-Üye Etkileşimi Arasındaki İlişki: Bir Devlet Üniversitesinde Araştırma. (Basılmamış Yüksek Lisans Tezi). Eskişehir: Eskişehir Osmangazi Üniversitesi İşletme Ana Bilim Dalı.

Dennis, S. R. ve Bocernea, M. (2005). Development of the Servant Leadership Assessment Instrument, Leadership \& Organization Development Journal, 26(8): 600-615.

Dinçer, K. M. ve Bitirim, S. (2007). Kurum Kültürü Çalışmalarında Hizmetkâr Liderlik Anlayışı ile Değer Yaratmak, İstanbul Üniversitesi Illetişim Fakültesi Hakemli Dergisi, 28: 61-72.
Ekpenyong, I. E. (2013). Effect of Employees' Perceptions of Their Managers' Leadership Styles on the Level of Sickness Presenteeism in the Workplace: A Cross Sectional, Quantitative Study. (Basılmamış Doktora Tezi). Amerika: Capella Üniversitesi Yönetim ve Liderlik Ana Bilim Dalı.

Ergen, F. D. (2013). Hizmetkâr Liderliğin Örgütsel Vatandaşlık Davranışına Etkisi: İstanbul ve Afyonkarahisar'daki Beş Yıldızlı Otel İşletmelerinde Bir Araştırma. (Basılmamış Yüksek Lisans Tezi). Afyonkarahisar: Afyon Kocatepe Üniversitesi Turizm İşletmeciliği ve Otelcilik Ana Bilim Dalı.

Eurofound. (2012). Fifth European Working Conditions Survey-Overview Report, Publications Office of the European Union, Luxembourg, https://www.eurofound. europa.eu/publications/report/2012/working-conditions/ fifth-european-working-conditions-survey-overview-report, Erişim tarihi: 6 Mart 2017.

Ferreira, A. I., Martinez, L. F., Cooper, C. ve Gui, D. M. (2015). LMX as a Negative Predictor of Presenteeism Climate: A Cross-Cultural Study in the Financial and Health Sectors, Journal of Organizational Effectiveness: People and Performance, 2(3): 282-302.

Firns, I., Travaglione, A. ve O'Neill, G. (2006). Absenteeism in Times of Rapid Organizational Change, Strategic Change, 15(3): 113-128.

Gilbreath, B. ve Karimi, L. (2012). Supervisor Behavior and Employee Presenteeism, International Journal of Leadership Studies, 7(1): 114-131.

Greenleaf, R. K. (1977). Servant Leadership: A Journey into the Nature of Legitimate Power and Greatness. New York: Paulist Yayınları.

Günbeyi, M. ve Gündoğdu, T. (2010). Polis Teşkilatının İşkolik Çalışanları, Doğuş Üniversitesi Dergisi, 11(1): 56-63.

Johns, G. (2010). Presenteeism in the Workplace: A Review and Research Agenda, Journal of Organizational Behavior, 31(4): 519-542.

Koçoğlu, M. (2007). İşletmelerde Presenteeism Sorunu ve İnsan Kaynakları Yönetimi Çerçevesinde Mücadele Yöntemleri. (Basılmamış Doktora Tezi). İstanbul: Yıldız Teknik Üniversitesi İşletme Ana Bilim Dalı.

Koopman, C., Pelletier, K. R., Murray, J. F., Sharda, C. E., Berger, M. L., Turpin, R. S., et al. (2002). Stanford Presenteeism Scale: Health Status and Employee Productivity, Journal of Occupational and Environmental Medicine, 44(1): 14-20.

Liden, C. R., Wayne, J. S., Zhao, H. ve Henderson, D. (2008). Servant Leadership: Development of a Multidimensional Measure and Multi-Level Assessment, The Leadership Quarterly, 19(2): 161-177.

Nielsen, K. ve Daniels, K. (2016). The Relationship Between Transformational Leadership and Follower Sickness Absence: The Role of Presenteeism, Work \& Stress, 30 (2): 193-208.

Oruç, Ş. (2015). Presenteizm İle Örgütsel Sessizlik Arasındaki İlişki Üzerine Bir Araştırma. (Basılmamış Yüksek Lisans Tezi). Aksaray: Aksaray Üniversitesi İşletme Ana Bilim Dall. 
Page, D. ve Wong, T. P. (2000). A Conceptual Framework for Measuring Servant- Leadership. İçinde S. Adjibolosoo (Editör), The Human Factor in Shaping the Course of History and Development (ss. 69-109). Lanham: Amerika Üniversitesi.

Patterson, A. K. (2003). Servant Leadership: A Theoretical Model. (Basılmamış Doktora Tezi). Amerika: Regent Üniversitesi Yönetim ve Liderlik Ana Bilim Dalı.

Pelit, E. (2008). İşletmelerde İşgören Güçlendirmenin İşgörenlerin İş Doyumuna Etkisi: Otel İşletmelerinde Bir Araştırma. (Basılmamış Doktora Tezi). Ankara: Gazi Üniversitesi Turizm İşletmeciliği Eğitimi Ana Bilim Dalı.

Samuel, R. J. ve Wilson, L. M. (2007). Is Presenteeism Hurting Your Workforce?, Employee Benefit Plan Review, 61(11): 5-7.

Schmid, J. A., Jarczok, M. N., Sonntag, D., Herr, R. M., Fischer, J. E. ve Schmidt, B. (2017). Associations Between Supportive Leadership Behavior and the Costs of Absenteeism and Presenteeism: An Epidemiological and Economic Approach, Journal of Occupational and Environmental Medicine, 59(2): 141-147.

Smith, D. J. (1970). Absenteeism and Presenteeism in Industry, Archives of Environmental Health, 21(5): 670-677.
Spears, C. L. (2010). Character and Servant Leadership: Ten Characteristics of Effective, Caring Leaders, The Journal of Virtues \& Leadership, 1(1): 25-30.

Sü, S. (1999). Konaklama İşletmelerinde Çalışan Personelin Sorunları ve Çözüm Önerileri. (Basılmamış Yüksek Lisans Tezi). Balıkesir: Balıkesir Üniversitesi Turizm İşletmeciliği Ana Bilim Dalı.

Ulu, S., Özdevecioğlu, M. ve Ardıç, K. (2016). Kişilik Özelliklerinin Hasta İken İşe Gelme (Presenteeizm) Davranışı Üzerindeki Etkileri: İmalat Sanayiinde Bir Araştırma, Erciyes Üniversitesi İktisadi ve İdari Bilimler Fakültesi Dergisi, 47: 167-181.

Vinod, S. ve Sudhakar, B. (2011). Servant Leadership: A Unique Art of Leadership, Interdisciplinary Journal of Contemporary Research in Business, 2 (11): 456-467.

Yazıcıŏglu, Y. ve Erdoğan, S. (2007). SPSS Uygulamalı Bilimsel Araştırma Yöntemleri (2. Baskı). Ankara: Detay Yayıncilık.

Yıldız, H. ve Yıldız, B. (2013), İş Yaşamında PresenteeismSözde Var Olma-Olgusu: Sağlık ve Verimlilik Açısından Önemi, 7. Sağllk ve Hastane İdaresi Kongresi Bildiriler Kitab1 (ss. 819-830). Konya.

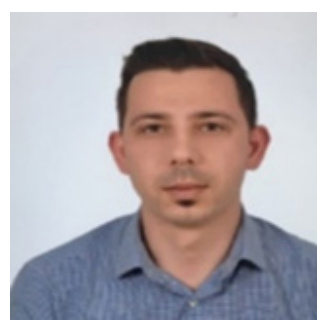

Necip ÖZDEMiR

Muğla Sıtkı Koçman Üniversitesi Turizm İşletmeciliği ve Otelcilik Yüksek Okulu Konaklama İşletmeciliği bölümünden mezun oldu (2014). Yüksek lisans derecesini Afyon Kocatepe Üniversitesi Turizm İşletmeciliği Ana Bilim Dalı'ndan aldı (2017). Anadolu Üniversitesi Turizm İşletmeciliği Ana Bilim Dalı Doktora Programı́nda öğrenimine devam etmektedir. Temel çalışma alanları, liderlik ve presentizmdir.

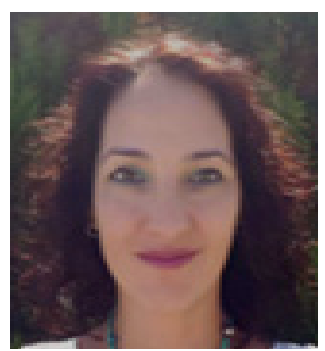

Esra GÜL YILMAZ

Anadolu Üniversitesi Turizm ve Otel İşletmeciliği Yüksek Okulu'ndan mezun oldu (2000). Yüksek lisans derecesini Anadolu Üniversitesi Turizm İşletmeciliği Ana Bilim Dalı'ndan (2007), doktora derecesini de Anadolu Üniversitesi Turizm İşletmeciliği Ana Bilim Dalı'ndan aldı (2013). Afyon Kocatepe Üniversitesi'nde çalışmaya başladı (2009). Halen Afyon Üniversitesi'nde görevine devam etmektedir. Temel çalışma alanları, turizm işletmeciliği, sürdürülebilirlik, liderliktir. 